\title{
The Management Of Character Education At School (Analysis Study At Surakarta Public Secondary School)
}

\author{
Rismiyati Nurindarwati \\ Kantor Kementerian Agama Kota Surakarta \\ rismiharjo@gmail.com \\ DOI: 10.18326/attarbiyah.v4i1.107-120
}

\begin{abstract}
Character education is a system to instil character values to students including the components of awareness, understanding, consideration, and profound commitment in implementing those character values. The character education applies at Surakarta public secondary school (SMPN Surakarta) to encourage character values to students on the components of knowledge, awareness, and interest for God the Almighty, individual, other people, and society. Character education at schools closely relates to management or school evaluation that how character education is planned and applied properly at schools. In planning character education, it can immerse character values into learning. The implementation itself tries to integrate character education contents that have been formulated into all learning subjects. The integration is in all aspects of school daily basis life such as teacher role models in behaving and teaching. The success of character education is evaluated by the achievement of indicators of output competency standard such as performing religious teaching properly, following social norms, capable to think logically, critically, creatively and innovatively, mastering knowledge for further education, and understanding personal and people rights and obligations during the life of local and national society.
\end{abstract}

Keywords: management, character education, schools 


\section{Introduction}

Indonesia requires adequate quantity and quality of human resources as the main support in development. In this sense, education plays an important role which is in line with the Act no 20 Year 2003 on national education system chapter 3. It states that national education system functions to develop skills, structure characters and prominent nation civilisation in order to uplift nation life. Meanwhile, chapter 1 asserts that education is an intentional and planned effort to create learning nuance and process, so students actively develop their potentials to have religious spiritual skills, self-control, society personality, noble characters, and skills needed by themselves, society, nation, and country . National education aims to develop students' potentials to be faithful and pious to God the Almighty, have noble characters, healthy, knowledgeable, creative, independent, democratic and responsible citizens.

Education is one of manifestations of dynamic and developed human culture, so the transformation and development in education becomes definite in line with the change of life culture. The transformation in terms of education improvement in all levels and fields is consecutively performed to anticipate the future. The objective of education is to structure competent and characterised individual. Therefore, the one will have a wide vision to achieve intended goals and capable to adapt fast and properly in any environment. The education itself motivates us to be better in all aspects of life. In order to achieve those functions and objectives, education in all levels including secondary 
school has to be organised well and systematically.

Character education is a system to instil character values to all school stake holders in order to acquire the components of knowledge, awareness or interest, and perform those values for God the Almighty, individual, other people, and society becoming human as a whole.

In character education at schools, all stakeholders must involve including the content of curriculum and evaluation, the quality of management correlation or learning subject organisation, school management, activity or extracurricular implementation, the use of structure and infrastructure, funding and working ethos of all school members and surroundings.

Character education at school also closely relates to management and school evaluation. The management means how character education is arranged, performed, adequately evaluated within educational activities at schools. The management includes intended values, curriculum, learning, evaluation, teachers and teaching staff, and related components. Thus, school management becomes effective media for character education at schools.

This research aim to reveal several important issues namely (1) understanding the concept of character education management at Surakarta public secondary school (SMPN Surakarta); (2) understanding the planning of character education at SMPN Surakarta; (3) understanding the implementation of character education at SMPN Surakarta; and (4) understanding the evaluation of character education at 
SMPN Surakarta.

\section{Methodology}

This study belongs to qualitative research which is phenomenologist. By using qualitative approach, this research aims to describe and find out comprehension on the management of character education in SMPN Surakarta. Qualitative research relates to non-numerical data, but they mainly come from library research of observation, interview, field notes, and documents. The researcher applies qualitative method in order to comprehend the phenomena, occurrence, and symptom evaluated on the aspects of concepts, planning, implementation, and supervision for character education in SMPN Surakarta.

The data analysis applies the following procedures:

1. Data collection uses observation / field exploration, interview and documentation. The collected data are edited, sorted out, and analysed descriptively.

2. Data reduction is conducted by selection, emphasising, simplifying, and removing the unrelated data.

3. Data presentation is an information sequence which is organised to lead the conclusion.

4. Conclusion or verification is by having data collection at the first place, reduction and data presentation, and respectively qualitative data analysis for thorough and accurate conclusion 


\section{Discussion}

According to George R. Terry, management is typical process quality consisting behaviours, planning, organisation, movement and control to define and achieve the goals in the use of human and other resources.

From that definition, management is the process of activities consisting planning, organising, movement and evaluation or supervision that have been arranged previously in order to effectively and efficiently meet the objectives.

Character education at school closely relates to management or school organisation. The management is about how character education is planned, organised, actualised, and evaluated in educational school activities.

The planning of character education at SMPN Surakarta

Planning is the whole process of defining all activities to perform in the future in order to achieve the intended purposes. Character values derived from religions, Pancasila, culture and national education goals become the main standard summarised in the items of output standard competencies and secondary material subjects for internalisation toward students.

The implemented character values include the ones related to God the Almighty 18 Being religious is attitude and behaviour in practicing religion teaching and tolerates the practice of other religions.

The character values related to individual are namely

1. Honesty is behaviour on the basis of spirit of becoming truthful 
personal in the words, conduct, and performance.

2. Responsibility is individual attitude and performance to accomplish duties and responsibility to oneself, society, country, and God the Almighty.

3. Discipline is an action displaying orderly and obedient behaviour towards rules and order

4. Creativity is a matter of thinking and doing something to create new things or alternatives

5. Independence is attitude and behaviour of counting more on oneself in doing the tasks.

6. Being tolerate is attitude and behaviour that considerate the diversity of religions, races, ethnics, arguments, actions and attitude.

7. Working hard is an action following and taking the rules.

8. Curiosity is behaviour and action in probing the details of something.

9. Teachable is attitude and behaviour of eagerly pursuing new knowledge.

10. Thinking logically, critically, creatively, innovatively.

The character values related to other people are namely

1. Being aware on personal and people rights and responsibility

2. Appreciating works and motivating others

3. Following social norms

4. Being democratic

5. Well behaved to people

The character values related to surrounding is being concern with social 
life condition and neighbourhood.

The character values related to nations are as the following:

1. Being patriotic and steady to defend the nation.

2. Considerate the diversity of the nation components.

The character values have to instil in creating character education at school. Further, it can be integrated into teaching and learning.

In learning, there are three terms; approach, method, and learning technique. Learning approach is typically general related to a set of assumption of learning standards. Whereas, learning method is a comprehensive planning in presenting learning materials systematically. Learning technique is specific activities implemented in the class based on approach and method taken.

In the structure of secondary school curriculum, each learning material basically has character aspects. However, there are two subjects that substantively have direct correlation with the development of attitude and noble characters; religious teaching and civic education. Those subjects explicitly evaluate values, integration of characters in the learning subjects in SMPN Surakarta that lead to value internalisation into daily basis behaviours during the learning process through the stages of planning, actuating, evaluation or controlling.

The actuation of character education at SMPN Surakarta

The program of character education in 2013 curriculum possesses many issues including structures, infrastructures, teacher, teaching staff, and students. 
The actuation is an activity of realisation into action in order to achieve the goal effectively and efficiently for values The stage of actuation becomes the main activity of character education.

The implementation of character education at schools needs to get through several steps such as:

1. Integrating the contents of character education that have been formulated into all learning subjects.

2. Integrating character education into daily school activities.

3. Developing communication, collaboration between schools with parents.

Many values that are important to instil to students can be integrated to the most appropriate learning subjects. Every learning subject will focus on the main value that relates to the characteristic of the learning subject. The effort is trying to orient the main value into certain learning subjects.

\begin{tabular}{|c|c|c|}
\hline No & Subject & Main Value \\
\hline 1 & Religious teaching & $\begin{array}{l}\text { Religious, honest, well mannered, discipline, } \\
\text { teachable, responsible, confident, consider the } \\
\text { religion diversity, following the social norms, } \\
\text { hard work, caring, healthy life style, }\end{array}$ \\
\hline 2 & Civic education & $\begin{array}{l}\text { Nationalist, democratic, honest, following social } \\
\text { norms, considering personal and people rights } \\
\text { and obligation }\end{array}$ \\
\hline 3 & $\begin{array}{l}\text { Indonesian } \\
\text { language }\end{array}$ & $\begin{array}{l}\text { Thinking logically, critically, creatively, } \\
\text { innovatively, confident, responsible, curious, } \\
\text { well mannered, nationalist }\end{array}$ \\
\hline 4 & Social science & $\begin{array}{l}\text { Nationalist, considering religion diversity, } \\
\text { thinking logically, critically, creatively and } \\
\text { normatively, concern with social life and } \\
\text { surrounding, possessing entrepreneurship }\end{array}$ \\
\hline
\end{tabular}


spirit, honest, hard work.

\begin{tabular}{ccccc}
\hline 5 & Natural science & $\begin{array}{l}\text { Curious, thinking logically, critically, creatively, } \\
\text { healthy life style, considering religion diversity, } \\
\text { discipline, independent, responsible, peaceful }\end{array}$ \\
\hline 6 & English language & $\begin{array}{l}\text { Considering religion diversity, confident, well } \\
\text { mannered, independent, following social } \\
\text { norms. }\end{array}$ \\
\hline 7 & Art and culture & $\begin{array}{l}\text { Considering religion diversity, nationalist, } \\
\text { respecting people works, honest, curious, } \\
\text { discipline, democratic }\end{array}$ \\
\hline 8 & Sports and health & $\begin{array}{l}\text { Healthy life style, work hard, discipline, honest, } \\
\text { confident, independent, respecting people } \\
\text { works and achievement. }\end{array}$ \\
\hline 9 & Hard skills & $\begin{array}{l}\text { Thinking logically, critically, creatively, } \\
\text { innovatively, independent, responsible, } \\
\text { respecting people works. }\end{array}$ \\
\hline 10 & Local subject & $\begin{array}{l}\text { Considering religion diversity, respecting } \\
\text { people works, caring and nationalist. }\end{array}$
\end{tabular}

Those main character education values are distributed into learning materials in SMPN Surakarta. On the other hand, the issues remain as in the following

a. Teacher understanding on the concepts of character education has not been comprehensive. Several of them have less concern with the actuation of character education.

b. There are also some teachers with insufficient competence to integrate the character values into the subject that they teach

To deal with the issues, the school principal conducts coordination meetings and gives explanation to the teachers on the importance of character education at schools. 
Besides, the principal has the teachers to take part in seminar or workshop held by state educational bureau to comprehend and implement character education at schools.

In the meeting of MGMP (regular teacher meeting on specific subject learning), school principals always assign teachers to take part in MGMP based on their subject teaching. During the discussion of character education, some teachers explain and share their experience in internalising character education values in their schools.

By the meeting, each teacher and practitioner are capable to understand and possess significant competency to internalise character values at schools.

4. Integrating character education in daily school activities

a. Implementing role modelling

The habituation of becoming role models is an activity of daily basis attitude for replication. The models are attitude and behaviour of teachers, teaching staff, and students by exemplifying proper conduct such as discipline and tidiness, politeness, compassion, caring, honesty, industrious, proper language etc.

b. Regular drill

It becomes one of character education activities integrated with daily basis school activities such as prayer, ceremony, cleaning maintenance of Friday tidiness etc.

5. Developing community with parents

a. School collaboration with parents 
The collaboration is in the hope of creating delighted, peaceful, and conducive ambience. So that it creates the atmosphere supporting character education. All roles of school stake holders become important aspects to support in creating the conducive nuance for character education.

b. School collaboration with surroundings

It is in need to have such collaboration. If school condition is safe, comfortable, well regulated, the learning process will be running orderly and enjoyable. Therefore, students are capable to think logically, critically, creatively, innovatively following the goals of character education.

The evaluation of character education at SMPN Surakarta

The evaluation is an effort to gain variety of information periodically and simultaneously on the process and result of development and improvement of student characters.

The purpose of evaluation is to measure the achievement of formulated values toward the minimal standards that have been developed and instilled at the school, so they can be internalised, practiced, applied, and maintained in the daily basis.

The success of the character education program can be seen from the indicator achievement by students as mentioned in the output competence standard for secondary school namely: 21

1. Students practice the religious teaching that they adhere to on the basis of youth development 
2. Demonstrating confidence

3. Following current social norms

4. Considering religion, culture, ethnic, race, and group diversity.

5. Having logic, critical, creative, innovative thought

6. Being able to learn independently

7. Being able to analyse and solve issues

8. Implementing healthy life style

9. Being able to communicate and interact effectively and politely

10. Understanding personal and people rights and obligation during the interaction with society, and respecting different opinions.

11. Considering cooperation and national culture

12. Possessing entrepreneurship spirit

13. Demonstrating eagerness in reading and writing

14. Mastering related knowledge to take further education

The evaluation of character education emphasises more on the acceptance of the values into daily attitude and behaviour. The method of evaluation of character education can be conducted by all teachers during learning process or out of process, inside or outside the class by having observation and note taking.

\section{Conclusion}

From the previous discussion, the researcher concludes as follow:

1. The character education at SMPN Surakarta is a planning system of character values for students including the component of knowledge, 
awareness, understanding, interest and action devoting those values for God the Almight, oneself, other people, and society. The actuation of character education closely relates to school management.

2. In the implementation of character education, it is through the stages of planning, organising, actuating, and controlling or evaluating, so the principles of character education are actualised and the purposes are achieved properly.

3. In planning the character education, the school integrates the character values with all learning subjects. All teachers apply the character education by integrating those values into the learning subject they taught. By so doing, the values will be internalised and comprehended easily. Thus, the students are capable to simply practice.

4. To evaluate the success of the character education at school, teachers can examine students during the learning process inside or outside the classes. Therefore, the achievement can be pictured from the reach of achievement indicators as in the output competence standard.

\section{Bibliography}

Ara Hidayat dan Imam Machali, Pengelolaan Pendidikan, Bandung, Educa, 2011.

Anton Athoilah, Dasar-Dasar Manajemen, Bandung, Pustaka Setia, 2010

Abdul majid dan Dian Andayani, Pendidikan Karakter Perspektif Islam, PT. Remaja Rosdakarta, 2011.

Akhmad Maulana dkk, Kamus Ilmiah Populer, Yogyakarta, Absolut, 2004. 
Akhmad Muhaimin Azzet, Urgensi Pendidikan Karakter di Indonesia, Yogyakarta, Ar Ruzz Media, 2011.

Departemen Pendidikan Nasional, Kamus Bahasa Indonesia, Jakarta, Pusat Bahasa, 2008.

George R. Terry alih bahasa oleh Winardi, Azas-azas Manajemen, Bandung, Alumni, 1986, hal. 163.

Kementerian Pendidikan Nasional, Pembinaan Pendidikan Karakter di

Sekolah Menengah Pertama, Jakarta, Kementerian Pendidikan Nasional, 2010.

Mulyasa, Manajemen Pendidikan Karakter, Jakarta, Bumi Aksara, 2011

Mansur Muslich, Pendidikan Karakter Menjawab Tantangan Kritis Multidimensional, Jakarta, Bumi Aksara, 2011

Sobri Sutikno, Manajemen Pendidikan Langkah Praktis Mewujudkan Lembaga Pendidikan Yang Unggul, Lomvok, Holistica, 2012.

Undang-Undang RI No. 20 tahun 2003 tentang Sistem Pendidikan Nasional, Yogyakarta: Pustaka Baru Press, 2005.

Novan Andri Wiyani, Manajemen Pendidikan Karakter, Konsep dan Implementasinya di Sekolah, Yogyakarta PT. Pustaka Insan Madani, 2012

Zubaidi, Desain Pendidikan Karakter, Konsepsi dan Implikasinya dalam Lembaga Pendidikan, Jakarta, Kharisma Putra Utama, 2011. 